\title{
Expression of the Wilms' tumor gene WT1 in the murine urogenital system
}

\author{
Jerry Pelletier,, ${ }^{1,4}$ Martin Schalling, ${ }^{1}$ Alan J. Buckler, ${ }^{1}$ Anne Rogers, ${ }^{1}$ Daniel A. Haber, ${ }^{1,3}$ \\ and David Housman ${ }^{1}$ \\ ${ }^{1}$ Center for Cancer Research, Massachusetts Institute of Technology, Cambridge, Massachusetts 02139 USA; ${ }^{2}$ McGill $^{2}$ \\ Cancer Center, McGill University, Montreal, Quebec, Canada, H3G 1Y6; ${ }^{3}$ Massachusetts General Hospital Cancer Center, \\ Harvard Medical School, Boston, Massachusetts 02114 USA
}

The Wilms' tumor gene WT1 is a recessive oncogene that encodes a putative transcription factor implicated in nephrogenesis during kidney development. In this report we analyze expression of WT1 in the murine urogenital system. WT1 is expressed in non-germ-cell components of the testis and ovaries in both young and adult mice. In situ mRNA hybridization studies demonstrate that WT1 is expressed in the granulosa and epithelial cells of ovaries, the Sertoli cells of the testis, and in the uterine wall. In addition to the 3.1-kb WT1 transcript detected by Northern blotting of RNA from kidney, uterus, and gonads, there is an $\sim 2.5-\mathrm{kb}$ WT1-related mRNA species in testis. The levels of WT1 mRNA in the gonads are among the highest observed, surpassing amounts detected in the embryonic kidney. During development, these levels are differentially regulated, depending on the sexual differentiation of the gonad. Expression of WT1 mRNA in the female reproductive system does not fluctuate significantly from days 4 to 40 postpartum. In contrast, WT1 mRNA levels in the tesis increase steadily after birth, reaching their highest expression levels at day 8 postpartum and decreasing slightly as the animal matures. Expression of WT1 in the gonads is detectable as early as 12.5 days postcoitum (p.c.). As an initial step toward exploring the tissue-specific expression of WT1, DNA elements upstream of WT1 were cloned and sequenced. Three putative transcription initiation sites, utilized in testis, ovaries, and uterus, were mapped by $\mathrm{S} 1$ nuclease protection assays. The sequences surrounding these sites have a high $G+C$ content, and typical upstream CCAAT and TATAA boxes are not present. These studies allowed us to identify the translation initiation site for WT1 protein synthesis. We have also used an epitope-tagging protocol to demonstrate that WT1 is a nuclear protein, consistent with its role as a transcription factor. Our results demonstrate regulation of WT1 expression during development of the gonads, implicate WT1 in genitourinary development, and provide a molecular framework toward understanding genitourinary defects observed among hereditary cases of Wilms' tumor.

[Key Words: Genitourinary development; Wilms' tumor; recessive oncogene; promoter]

Received February 6, 1991; revised version accepted May 21, 1991.

Wilms' tumor (WT), or nephroblastoma, is an embryonal malignancy of the kidney, arising from the metanephric blastema, that affects $\sim 1$ in 10,000 children (Matsunaga 1981). A genetic predisposition is correlated with constitutional deletions within chromosome 11 band p13 (Riccardi et al. 1978; Francke et al. 1979). These cytogenetic observations provided initial support for a recessive model of Wilms' tumorigenesis by suggesting that nephroblastomas result from loss of function of a gene at $11 \mathrm{p} 13$. The hereditary cases of WT show a high association with congenital aniridia (AN2), genitourinary (GU) malformations, and mental retardation (the WAGR syndrome) (Miller et al. 1964). This constellation of anomalies, which show variable expressivity and incomplete penetrance, define a cluster of genes within $11 \mathrm{p} 13$ that

${ }^{4}$ Corresponding author. are important in the development of the iris, kidney, urogenital tract, and brain.

A candidate WT gene (WT1) from $11 \mathrm{p} 13$ has recently been cloned (Call et al. 1990; Gessler et al. 1990). All or part of WT1 is homozygously deleted in a small but highly diagnostic set of sporadic WTs (Lewis et al. 1988; Gessler et al. 1990). Small deletions of the WT1 gene in sporadic and hereditary WTs have also been observed (Haber et al. 1990; Huff et al. 1991), providing molecular evidence for disruption of this gene within WTs. WT1 expression during nephrogenesis in the kidneys is limited to the condensed mesenchyme, renal vesicle, and glomerular epithelium (Pritchard-Jones et al. 1990). The predicted WT1 polypeptide sequence shows several features characteristic of a transcription factor (i.e., four Cys-His zinc finger domains and a region rich in prolines and glutamines) (Call et al. 1990; Gessler et al. 1990). 
Four distinct WT1 mRNAs are produced in the kidney, reflecting the presence or absence of two alternative splice sites (D. Haber, R. Sohn, A. Buckler, J. Pelletier, K. Call, and D. Housman, unpubl.). Presumably, WT1 is involved in kidney organogenesis.

GU anomalies are relatively common in the general population, and their expression varies greatly among WAGR patients. Malformations involve the kidney, collecting system, and external genitalia and include aplastic or hypoplastic kidneys, horseshoe kidneys, urethral anomalies, hypospadias (misplaced external penile urinary orifice), cryptorchidism (undescended testis), and ambiguous genitalia (Drash et al. 1970; Pendergrass 1976; Turleau et al. 1981; Breslow and Beckwith 1982). The positions of the genes in the WAGR complex responsible for cryptorchidism and hypospadias have been localized to a $350-$ to $400-\mathrm{kbp}$ region that also encompasses the WT1 gene (van Heyningen et al. 1990). GU defects are associated more often with bilateral WT than is AN2, suggesting that the GU gene is linked more intimately to the WT1 gene than AN2 is (Pendergrass 1976). Several recent studies have suggested that the WT1 gene product itself is involved in GU development. (1) WT1 is expressed in the GU system. The main sites of expression are the fetal gonad, genital ridge, ovary, testis (Pritchard-Jones et al. 1990; this report), and uterus (this report). (2) Genetic analysis with restriction fragment length polymorphism (RFLP) and dosage analysis of 36 genetic markers failed to reveal any rearrangements or deletions of $11 \mathrm{p} 13$ in a child with bilateral WT and hypospadias (patient PG; Glaser et al. 1989). This child has been found to carry a 17-bp deletion within WT1, which disrupts an exon upstream of the zinc-finger domains and creates an in-frame stop codon. This mutation is converted to homozygosity in both of the child's WTs, which presumably initiated malignant transformation (J. Pelletier, W. Bruening, F. Li, D. Haber, and D. Housman, unpubl.). (3) An association between genital and urinary system anomalies with early onset WTs and intralobar nephroblastomatosis has also been suggested on the basis of statistical data (Breslow et al. 1988; Beckwith et al. 1989).

As an initial step toward developing an animal model for WT and WT-associated anomalies /developmental and tumorigenic), we have recently isolated several murine WT1 cDNAs (Buckler et al. 1991). We have analyzed WT1 expression in the developing gonads because, embryologically and anatomically, the genital system is closely linked to the urinary system-both developing from a common ancestral mesodermal ridge (the intermediate mesoderm). In this report we demonstrate that WT1 is expressed in the granulosa cells of the ovaries, the Sertoli cells of the testis, and the myometrium of the uterus. Expression of WT1 in the fetal gonad was detected as early as day 12.5 postcoitum (p.c.). We have isolated sequences upstream of our longest cDNA and have mapped several putative transcription start sites for the WT1 gene. This analysis has enabled us to determine the start site of translation for WT1. We have also used an epitope-tagging strategy to demonstrate that WT1 is a nuclear factor, consistent with its predicted role as a transcription factor.

\section{Results}

Expression of WT1 in murine gonads

WT1 has been implicated in GU development (Glaser et al. 1989; Pritchard-Jones et al. 1990; van Heyningen et al. 1990). This idea is supported by the elevated frequency of GU anomalies associated with WT cases and by the common embryological origins of the genital system and the metanephric kidney. Expression of WT1 is limited to a small number of tissues in mammals. In humans, WT1 expression has been detected in fetal kidney, ovary, spleen, and testis (Haber et al. 1990; Pritchard-Jones et al. 1990). Northern blot analysis of RNA isolated from various baboon tissues has also demonstrated high levels of WT1 mRNA in spleen and kidney and low levels in heart (Call et al. 1990). In mice, high levels of expression have been observed in the kidney and spleen, whereas heart, lung, and thymus show low detectable levels of WT1 (Buckler et al. 1991).

To evaluate the pattern of WT1 expression in murine gonads, we performed Northern blot analysis on total RNA isolated from adult ovaries and testis (Fig. 1). A murine WT1 cDNA was used as a probe and found to hybridize a 3.1-kb RNA transcript present in total RNA isolated from testis (lanes 1, 4, and 5), ovaries (lane 3), and adult kidney (lane 6). This transcript is not present in total RNA from adult liver (lane 2). Interestingly, an $\sim 2.5$-kb mRNA transcript, unique to testis, is detected with the WT1 probe (lanes 1, 4, and 5). Because many genes expressed in germ cells have transcripts that differ in structure from those found in somatic cells (Propst et al. 19881, we attempted to determine whether expression of the $\sim 2.5-\mathrm{kb}$ mRNA species was the result of germ cell-specific transcription. We prepared total RNA from gonads isolated from $\mathrm{SI} / \mathrm{SI}^{\mathrm{d}}$ and $\mathrm{W} / \mathrm{W}^{\mathrm{v}}$ mice. These mice are devoid of germ cells because of the failure of the germ cells to migrate to the genital ridge during embryogenesis (Bennett 1956; Mintz and Russel 1957). Both WT transcripts are detected in RNA preparations from testis of $\mathrm{SI} / \mathrm{SI}^{\mathrm{d}}$ and $\mathrm{W} / \mathrm{W}^{\mathrm{v}}$ mice (lanes 4 and 5 , respectively), demonstrating that the shorter $\sim 2.5-\mathrm{kb}$ mRNA transcript is not a result of alternative processing of the WT1 gene within the sperm cells.

\section{Developmental regulation of WT1 in the gonads}

During kidney development in the mouse, WT1 expression peaks between day 17 of gestation and day 3 after birth and then declines 20-fold during maturation to adulthood (Buckler et al. 1991). We have analyzed WT1 expression in the developing gonads. Total RNA isolated from the reproductive system of female mice 4, 20, and 40 days after birth was analyzed by Northern blotting. The WT1 cDNA hybridizes to a $3.1-\mathrm{kb}$ mRNA species whose levels do not significantly fluctuate after day 4 postpartum (Fig. 2A, cf. lanes 1-3). Variations in load- 


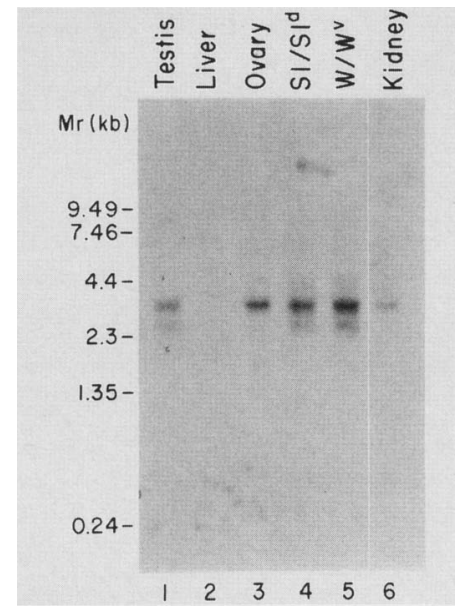

Figure 1. (A) Northern blot analysis showing expression of WT1 in urogenital organs. RNA was isolated from organs of adult mice, as indicated in Materials and methods, and $15 \mu \mathrm{g}$ was analyzed on a $1.2 \%$ agarose $/ 37 \%$ formaldehyde gel. (Lane 1 ) Testis; (lane 2) liver; (lane 3) ovary; (lane 4) testis from SI/SI mice; (lane 5) testis from $\mathrm{W} / \mathrm{W}^{\mathrm{v}}$ mice; (lane 6) kidney. The probe was a mouse WT1 cDNA (pMWT2), which encompasses nucleotides 727-3089 of the sequence presented by Buckier et al. (1991). The sizes indicated to the left (in $\mathrm{kb}$ ) were determined from BRL RNA sizing standards, which were electrophoresed in parallel and visualized by staining with acridine orange. The blot was exposed to X-Omat AR film (Kodak) at $-70^{\circ} \mathrm{C}$ for 48 hr. Equal RNA loadings among samples were verified by ethidium bromide staining and visualizing the rRNA bands (data not shown). The levels of the testis-unique $\sim 2.5-\mathrm{kb}$ mRNA testis transcript are about threefold lower than those of the 3-kb species (as determined by quantitating the Northern blot with a Molecular Dynamics Phosphoimager).

ing among the RNA samples were accounted for by reprobing the same filter with a mouse $\beta$-actin probe (Fig. 2B).

Expression of WT1 was also analyzed in the developing testis (Fig. 3A). The levels of the 3.1-kb WT1 transcript in testis isolated from mice 1 day postpartum are as high as those observed in kidneys from mice of the same age (cf. lane 3 with lane 1). Very little of the $2.5-\mathrm{kb}$ mRNA transcript is observed. The levels of the $3.1-\mathrm{kb}$ mRNA transcript in testis peak at day 8 postpartum (threefold increase relative to levels at day 1) and decline twofold as the testis mature. The $2.5-\mathrm{kb}$ transcript is maximally expressed around day 15 postpartum (Fig. 3A, lane 6 ) and does not vary significantly from that point to adulthood. A high-molecular-weight mRNA species is also observed to hybridize with WT1. The levels of this mRNA species vary among mRNA preparations, and we believe that the species is an unprocessed nuclear WT1 precursor. Figure 3B shows the same blot rehybridized with a mouse $\beta$-actin probe. We conclude from these studies that WT1 expression is tightly regulated in the testis.

\section{Expression of WT1 in the murine reproductive system}

To better characterize WT1 expression and define the cell type expressing WT1 in the murine reproductive system, we performed in situ RNA hybridization on mouse ovary, testis, and uterus (Fig. 4). In ovaries isolated from mice 17 days postpartum, WT1 RNA is expressed at high levels in peripherally located follicles (Fig. 4A, large arrows) and in the epithelial cell layer of the ovary (Fig. 4A, small arrows). Expression was also detected in the fimbria of the fallopian tube (denoted by a white star). A higher magnification of Figure 4A shows that expression of WTI within the follicles is limited to the granulosa cells and increases with follicular maturation (Fig. 4B). No specific hybridization was detected when a WT1 sense oligonucleotide was used to probe a serial section (Fig. 4C).

To determine the cell type within the testis responsible for the high levels of expression observed in that organ (Fig. 3), we performed in situ hybridizations on serial sections of testis isolated from mice 17 days postpartum. Expression is limited to the seminiferous tubules (Fig. 4D) and occurs within the Sertoli cells (Fig. $4 \mathrm{E}$, arrowheads). It is unlikely that any significant WT1 expression occurs in the germ cell component because testis devoid of sperm cells also expresses high levels of WT1 (Fig. 1). No hybridization was detected in the epididymis or vas deferens of the testis (data not shown),

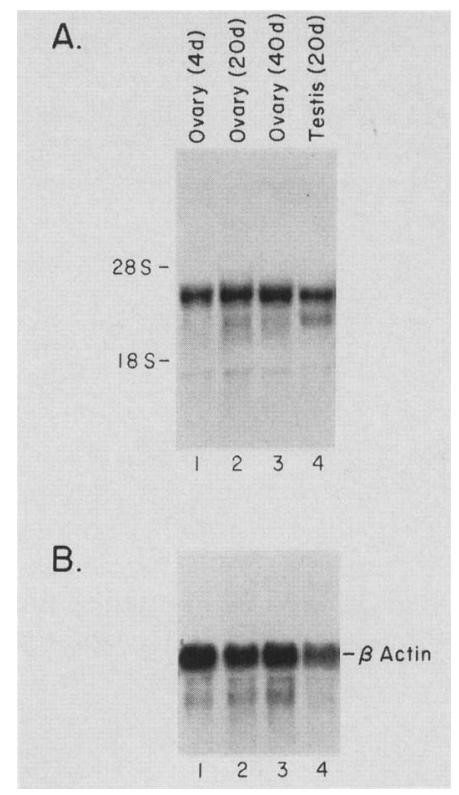

Figure 2. Expression of WT1 in the developing female reproductive tract. $(A)$ RNA was isolated from the reproductive system (ovaries, fallopian tubes, and uterus) of mice at various times postpartum, as indicated by lane labels. Fifteen micrograms of total RNA was used for Northern blot analysis. The probe was a mouse WT1 cDNA (pMWT2), which encompasses nucleotides 727-3089 of the sequence based on data from Buckler et al. (1991). The sizes indicated to the left (in $\mathrm{kb}$ ) were determined from BRL RNA sizing standards, which were electrophoresed in parallel and visualized by staining with acridine orange. $(B)$ Reprobing the same fllter with a $\beta$-actin cDNA probe. 


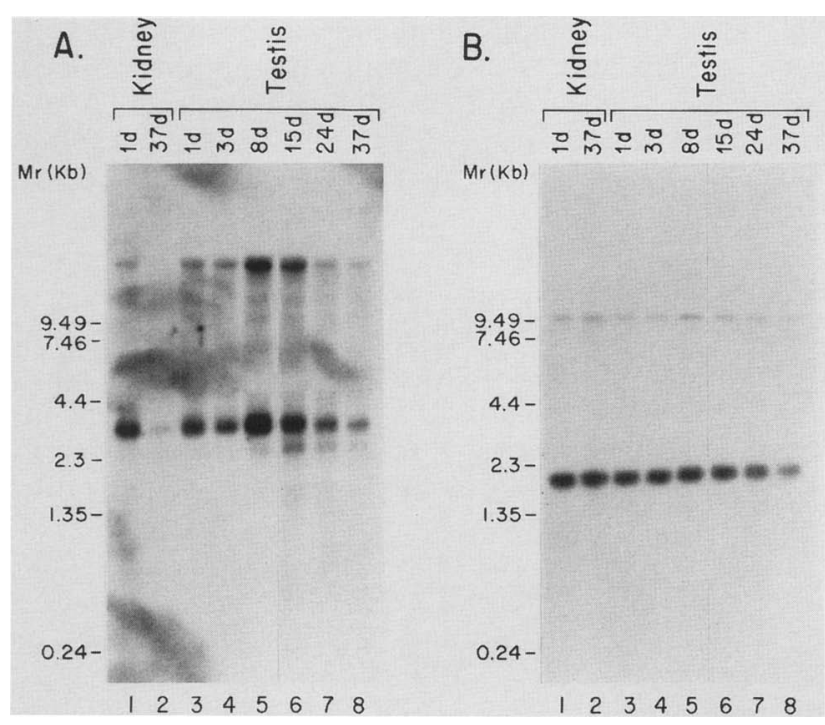

Figure 3. Expression of the WT1 gene in developing testis. $|A|$ RNA was isolated from the testis of mice at various times postpartum as indicated by lane labels. Fifteen micrograms of total RNA was used for Northern blot analysis. The probe was a mouse WT1 cDNA (pMWT2). The sizes indicated to the left (in kb) were determined from BRL RNA sizing standards, which were electrophoresed in parallel and visualized by staining with acridine orange. $(B)$ Reprobing the same filter with a $\beta$-actin cDNA probe. Mouse testis contains two size classes of $\beta$-actin mRNA ( 2.1 and $1.5 \mathrm{~kb}$ ) that are differentiaily expressed during spermatogenesis (Waters et al. 1985). The 1.5-kb mRNA is not visible on this exposure because it represents a very minor species and does not appear until round spermatids are formed (about day 20 postpartum) (Waters et al. 1985). It is detectable upon prolonged exposure of the Northern blot (data not shown).

nor when a serial section was hybridized with a sense WT1 probe (Fig. 4F).

In situ RNA hybridization experiments on a section of a uterus isolated from a 17-day-old mouse demonstrated labeling over the myomemum and endometrial stroma (Fig. 4G). However, the epithelial components of the endometrium were unlabeled (see arrows in Fig. $4 \mathrm{H}$ ). No expression was observed when a sense WT1 probe was used for hybridization studies (Fig. 4I).

\section{Expression of WT1 in kidneys and testis of Seydey/+ mice}

A mouse model of the AN2-WT deletion syndrome has recently been described (Glaser et al. 1990). Southern blot analysis of DNA isolated from Sey ${ }^{\mathrm{dey}} /+$ mice have revealed that WT1 is hemizygously deleted (Buckler et al. 1991). To analyze the pattern of expression of WT1 in these mice, we performed in situ RNA hybridizations on kidneys and testis isolated from 17-day-old littermates produced by crossing a Sey ${ }^{\mathrm{dey}} /+\mathrm{C} 57 \mathrm{BL} 6$ female and a C57BL6 male (Fig. 5). In situ hybridization on a kidney from a normal offspring revealed intense labeling over the glomerulus, as detected previously by Pritchard-
Jones et al. (1990) (Fig. 5A). Similar levels of WT1 mRNA were observed in kidneys from Seydey/ + offspring (Fig. 5B). WT1 expression in testis from C57BL6 (Fig. 5C),

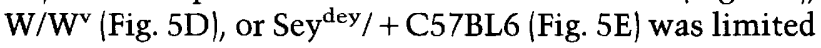
to the Sertoli cells.

\section{The murine WT1 gene is expressed in the fetal gonad}

A postulated role of WT1 in gonadal development requires that WTI be expressed during embryogenesis. Pritchard-Jones et al. (1990) have documented expression of WT1 in the developing gonad of a 49-day gestation human embryo. We have extended these results and analyzed expression of WT1 in the developing gonad of a 12.5-day-old mouse embryo (Fig. 6). Transverse sections from a 12.5-day p.c. embryo were prepared and hybridized to a ${ }^{35}$ S-labeled oligonucleotide probe corresponding to WT1. No labeling was observed when a sense oligonucleotide probe was used (Fig. 6A) or in the mesonephrous duct or regressing mesonephrous tubules (Fig. 6B). WTl was highly expressed in the developing gonad and to a lower extent in the mesonephrous. Using oligonucleotides targeted to Sry, we amplified this Y chromosome gene from tissue sections successfully by polymerase chain reaction $(\mathrm{PCR})$, indicating that this was a male embryo (J. Pelletier, unpubl.).

\section{Determination of transcription initiation sites and nucleotide sequence of the WT1 5'-flanking region}

As a first step toward defining the molecular basis of WT1 tissue-specific expression (see Figs. 1, 3, 4, and 6), we isolated genomic sequences extending upstream of our longest cDNA, as described in Materials and methods. The partial sequence presented in Figure 7A extends the known nucleotide sequence of the murine WT1 gene by 495 nucleotides.

In an attempt to define the transcription initiation sites of WT1, we performed S1 protection experiments with two probes derived from this region: an EcoRI-EagI fragment (410 bp; Fig. 7B) and an EagI-PpuMI fragment $(480 \mathrm{bp})$ (Fig. $7 \mathrm{C})$. The positions of the protected bands (I-III), with respect to the molecular mass markers and a DNA sequencing ladder (not shown), suggested that WT1 transcription is initiated at positions $+1,+25$, and +337 (see Fig. 7A). The accuracy for the initiation sites is $\sim 5 \mathrm{bp}$. All three mRNAs are present in the same proportions in testis, ovaries (Fig. $7 \mathrm{~B}, \mathrm{Cl}$, and uterus (not shown). The larger WT1 mRNA species (band I on Fig. 7B) in the testis RNA sample lane is visible after prolonged exposure of the blot (data not shown). These results imply that three WT1 mRNA species ranging in size from $\sim 3340, \sim 3320$, and $\sim 3000$ bp are synthesized. The smaller WT1 transcript detected by the S1 protection analysis (band III; Fig. $7 \mathrm{C}$ ) is most likely not an alternatively spliced product, because anchored RNAbased PCR extension with primers to cross this S1-sensitive site failed to reveal any novel spliced products (J. Pelletier, unpubl.|. Rather, only cDNA sequence contiguous with the genomic sequence was obtained, presum- 

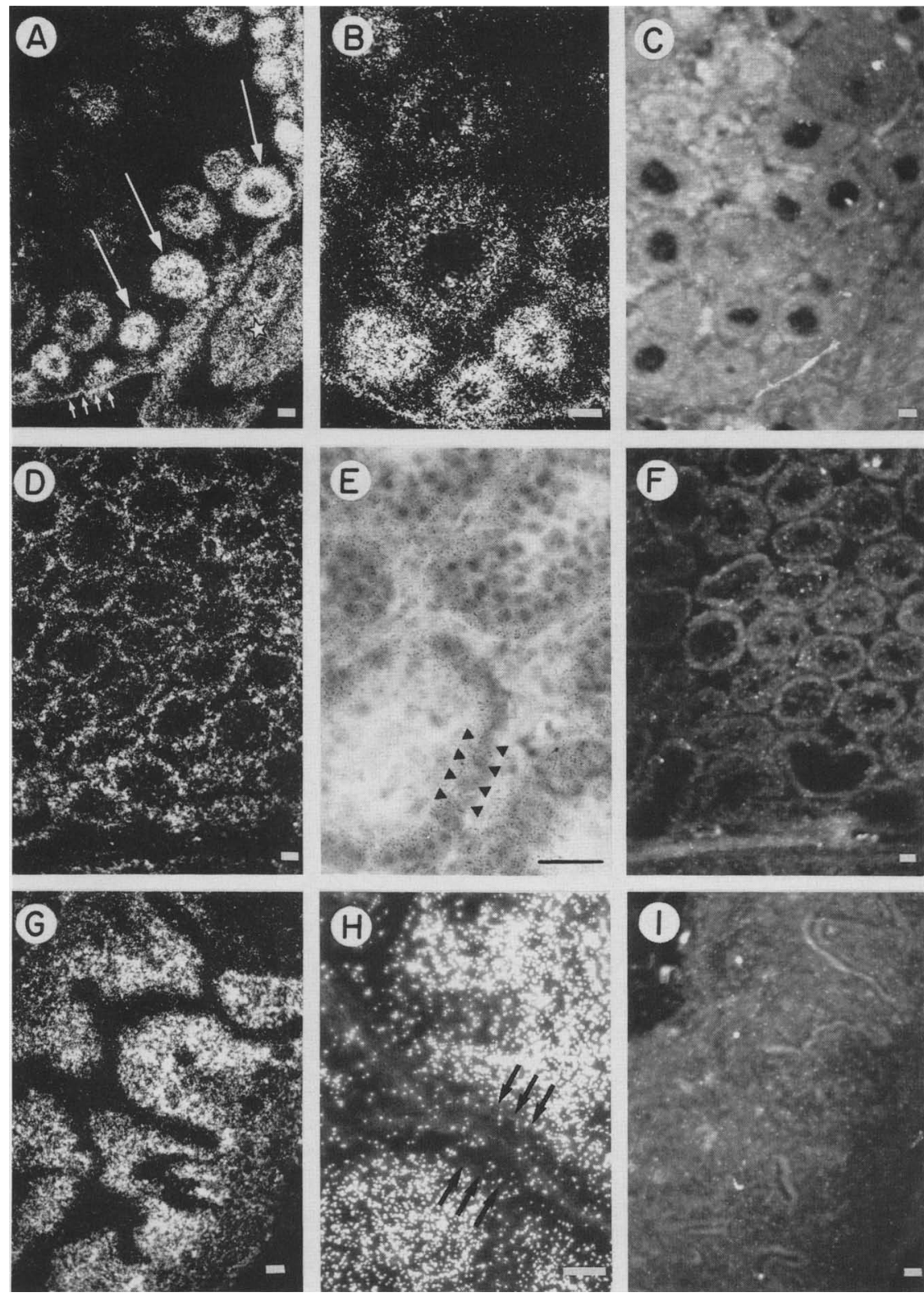

Figure 4. In situ RNA hybridization with ${ }^{35} \mathrm{~S}$-labeled WT1 oligonucleotide probe to sectioned murine ovaries, testis, and uterus. Presented are the autoradiographs of 17-day-old mouse ovary $(A-C)$, testis $(D-F)$, and uterus $(G-I)$ after in situ hybridization with oligonucleotide probes complementary to WT1 mRNA $(A, B, D-$ $E, G-H)$ and sense strand $(C, F, I)$. The WT1 mRNA is visualized as silver grains using dark-field illumination in all except $E$, where bight-field illumination was used. (A) Cross section through an ovary. Intense labeling is apparent in the granulosa cells of peripherally located follicles (large arrows), in the epithelial cell layer of the ovary (small arrows), and in parts of the fimbriae (white star), with no signal present in the oocytes or stroma surrounding the follicles. $(B)$ Higher magnification of $A$ showing increase in follicular labeling close to ovarian surface. $(C)$ Adjacent section to $A$ hybridized with sense probe of WT1 showing random grain distribution. Note the presence of similar follicles more centrally located that express low or no levels of WT1. (D) Cross section through a testis. Strong hybridization is seen in the basal parts of all seminiferous tubules. (E) Bright-field image of seminiferous tubules. Grains are located over the peripheral one-third of the tubules. Very low or no labeling is present over interstitial cells. $(F)$ Dark-field image of a section adjacent to $D$ hybridized with a sense probe to WT1 mRNA. Only random grain distribution is present. $(G)$ Longitudinal section of part of the uterus. Intense labeling is present overlying most of the uterine wall, excluding only the endometrial lining and the most peripheral cell layers. $(H)$ Detail of $G$ showing lumen and endometrial epithelium (arrowheads) unlabeled, whereas high-grain density is seen over endometrial stroma and myometrium. (I) Section semiadjacent to $G$ probed with sense probe. Bars in bottom right corners, $100 \mu \mathrm{m}$. Sections were exposed for 17 days. ably a result of priming from the two larger WT1 mRNA transcripts (bands I and II, Fig. 7B). The smaller WT1 transcript can be resolved from the larger species by prolonged electrophoresis on $1.2 \%$ agarose $/ 37 \%$ formaldehyde gels (data not shown). We note the presence of two small open reading frames (ORFs) within the 5 '-untranslated region (UTR) of the longer, less abundant WT1 transcripts. The shorter, more prevalent WT1 transcript does not contain these ORFs within its 5' UTR. A region spanning positions -100 to +600 is rich in guanines and cytosines, which constitute $67 \%$ of the total bases in the region.

We attempted to define the differences in size between the $\sim 3.1$ - and $\sim 2.5-\mathrm{kbp}$ WT1 mRNA species observed in the testis (Figs. 1 and 3). The appearance of this transcript coincides with the appearance of spermatids in the testis. The WT1 polyadenylation site has been defined as AATTAA (Buckler et al. 1991) and lies 21 nucleotides from the 3 ' end of the WT1 polyadenylation tract. However, close inspection of the $3^{\prime}$ UTR of WT1 reveals another AATAAA signal, 800 nucleotides from the poly(A) tail. Although none of our 11 murine testis cDNA clones had a poly(A) tract near this site (J. Pelletier, unpubl.), we investigated the possibility that alternative polyadenylation was responsible for generating the $2.5-\mathrm{kb}$ mRNA transcript. We performed Northern blot analysis on total 


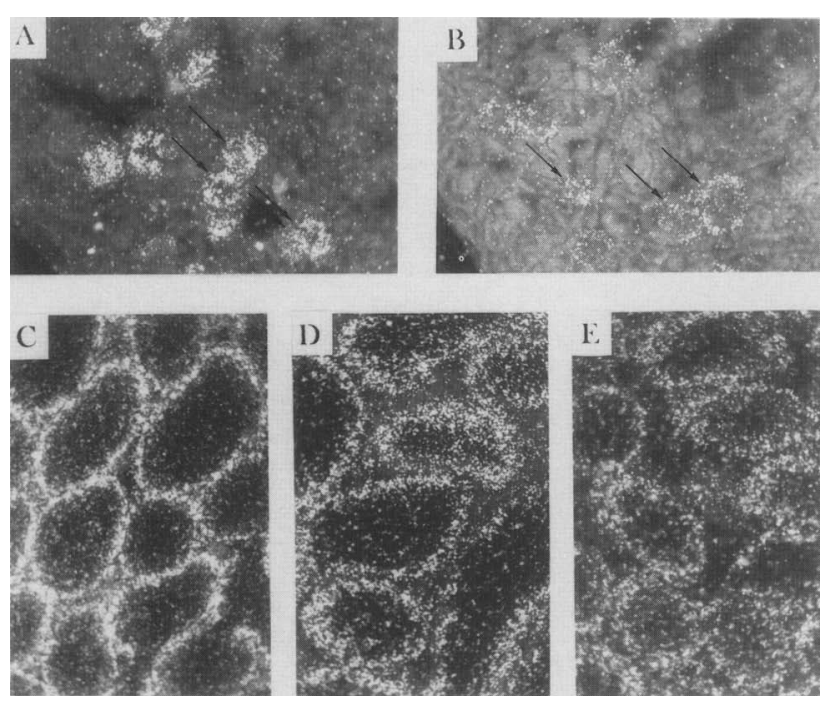

Figure 5. In situ RNA hybridization with ${ }^{35}$ S-labeled WT1 oligonucleotide probe to sectioned murine kidneys and testis. In situ hybridizations were performed on 17-day postpartum kid-

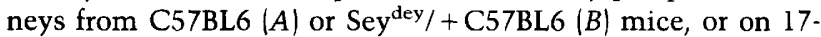
day postpartum testis from C57BLb mice $(C)$, adult testis from $\mathrm{W} / \mathrm{W}^{\mathrm{v}}$ mice $(D)$, and 17-day postpartum testis from Sey ${ }^{\mathrm{dey}} /$ + C57BL6 mice $(E)$. Presented are the autoradiographs after 21 days of exposure. The WT1 mRNA is visualized as silver grains using dark-field illumination. Arrowheads denote WT1 expression in the glomeruli $(A, B)$. Kidney and testis sections from Sey ${ }^{\text {dey }} /+$ C57BL6 and C57BL6 were mounted adjacent to each other on microscope slides and were subjected to identical experimental manipulations. Note that testis from the $W / W^{v}$ mouse $(D)$ is not age-matched and is included to demonstrate that WT1 labeling in the seminiferous tubules is not germ cell specific.

RNA isolated from adult testis and fetal kidney (17 days gestation) with a 3 '-end-specific DNA probe that hybridized to 305 bases upstream of the poly(A) tail. This probe recognized both mRNA species (data not shown). S1 nuclease protection experiments with probes to the $3^{\prime}$ UTR of WT1 failed to reveal any evidence for alternative processing in this region (data not shown). A similar analysis within the coding region of WT1 failed to define the basis for the difference in size of the $\sim 2.5-\mathrm{kb}$ mRNA transcript. This type of analysis could not be performed using specific DNA probes from the $5^{\prime}$ end of the WT1 gene because hybridization with fragments from this region resulted in nonspecific hybridization, presumably a reflection of the high $G+C$ content $>80 \%$ in some areas) of this region. Therefore, the alternative processing event that gives rise to the $2.5-\mathrm{kb}$ WT1 transcript is currently undefined.

There are no CCAAT or TATAA boxes in the sequence immediately preceding any of the putative transcription start sites of WT1. The most recognizable sequence motifs detected within the upstream region of WT1 are the 5'-GGGCGG-3' (or 5'-CCGCCC-3') motifs, the binding sites for transcription factor $\mathrm{Spl}$ (Jones et al. 1988), which occur at three positions: $-67,+178$, and +427 . The significance of these sequences is unknown, although they may be important for transcription initiation in TATAA-less promoters (see Discussion). Rauscher et al. (1990) have recently used an in vitro $\mathrm{DNA}$ /protein-binding assay to demonstrate that the zinc finger domain of WT1 can bind to the EGR-1 consensus sequence [5'-CGCCCCCGC- $\left.3^{\prime}\right]$ and closely related sequences. We note the presence of two related sequences within the WT1 promoter (Fig. 7A, stippled boxes) raising the possibility that WT1 may regulate its own transcription.

\section{The WT1 polypeptide is localized in the nucleus}

From features of the predicted amino acid sequence of WT1 (Call et al. 1990; Gessler et al. 1990), we have suggested that it may have DNA-binding activity. Rauscher et al. (1990) have recently demonstrated such an activity in vitro with protein-DNA mobility-shift assays. A prerequisite for these functions in vivo is localization within the nucleus. Cellular sublocalization of proteins

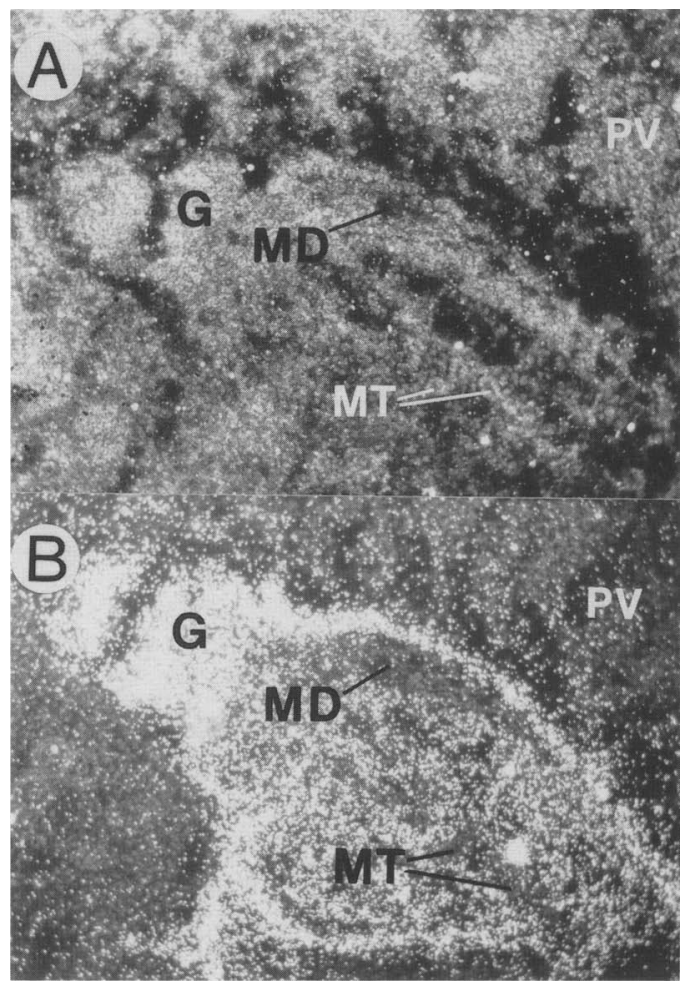

Figure 6. Expression pattern of WT1 in the developing gonads of a mouse embryo as revealed by in situ mRNA hybridization. In situ hybridizations with ${ }^{35} \mathrm{~S}$-labeled WT1 sense $(A)$ and antisense $(B)$ to a transverse section of a 12.5-day p.c. mouse embryo are presented as autoradiographs of 9-day exposures. The WT1 mRNA is visualized as silver grains with dark-field illumination. (A) No specific labeling is observed over any embryonic structures with the sense WTl probe. $(B)$ Heavy labeling is seen over the gonad (G), the mesonephrous, and the epithelial layer lining the coelomic cavity with the antisense WT1 probe. The mesonephric duct (MD), regressing mesonephric tubules $(\mathrm{MT})$, and prevertebrate (PV) are unlabeled. 
ACACTTCATA ATTATCTATC CCGAACAATT TCACCTTGAA TCTCAACCTG

CGAACCCAGA GGGACTAATC TCCTAAAGTG ACCCCGCAGC TAGCCTCTAG

AATCTGGAC ATGGGAGGAG ATAAGCCCCA AAGTTAGGCT ATCTGCCTCA Eco RI

$+1 \underset{\text { CTCCTACTTC GGTCCGACAC CGAGGGGACT CATTACTTAC CTAGACGCCT }}{\longrightarrow}$

TGCCTCAAGG CGCCTACACT CGGGAAGGCC AGCTAGGGTA GCAGGGGGAG

GCTTGCGGTA CAGGCCAGCT GAGAGCACGT GGCGGGCCAG AGAGGAGGGT GTCTCCGAGA TGAACGCTCC CTCGGG CCG CCGCA ACCC CCGGTGCTAG

IAACCGGGAC GAGCAGCGCG CTTTGCTGAG CTAGGCTAGG GCTGCTGTGT

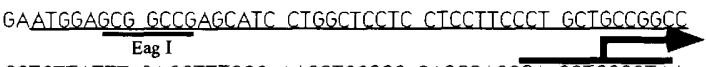
CCTCTTATII GAGCTTTGGG AAGCTGGGGG CAGCCAGGCA GCTGGGTAA

GGAGTTCAAG GCAGCGCCCA CACCCGGGGC TCTCCGCAAC CCGACCGCCT

GCCTGCCTCC CCCTTTCCTT TTTTCCDCGC CCDTCCCTCC CACCCACTCA

TTCACCCACC CACCCAGAGA GAGGACGGCA GCCCAGGAAC CCGgGCCCGC

+500 CGCCTCCTCG CCGCGATCCT GGACTTCCTC CTGTCGCAGG AGCCGGCTTC

CACGTGTGTC CCGGAGCCGG CGTCTCAGCA CACGCTCCGC CGGGAGCCCG

GGTGCGTCCA GCAGCCGGAG CAACCTGGGG ACCGAGGCCC CCGGAGCGCC

TGGGCCAAGT CCAGCGCCGA GAATCCGCAG GATCGCAGGA GCGGAGAACC

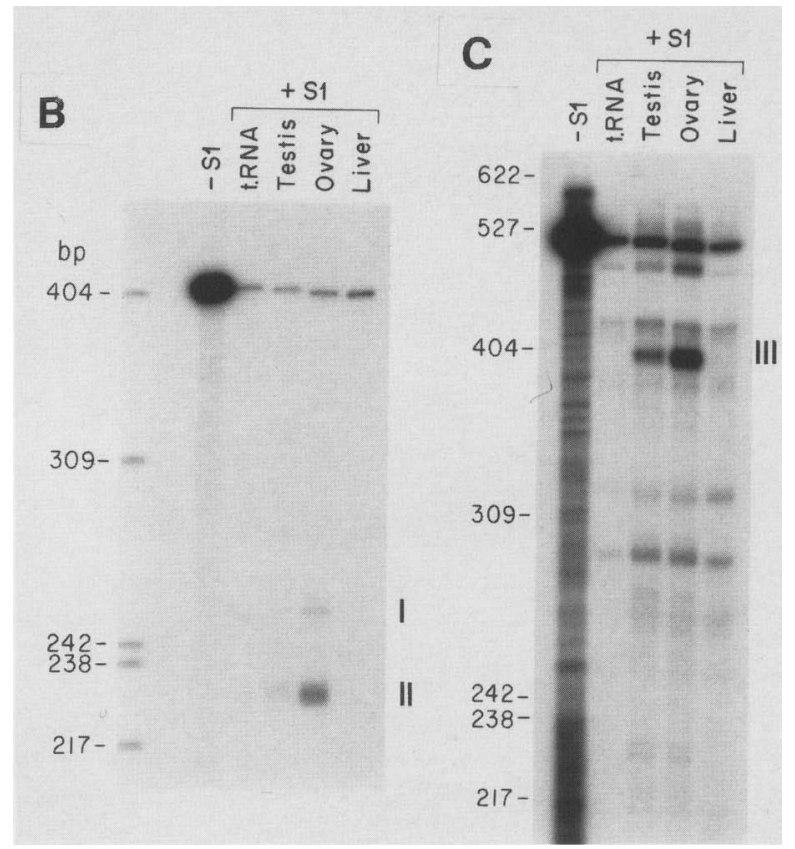

Figure 7. SI analysis and nucleotide sequence of the WTl $5^{\prime}$-flanking region. $(A)$ Position +1 denotes a putative transcription start site and corresponds to the higher molecular mass-protected species shown in $B$. Right-angled arrows indicate positions where initiation of WT1 transcription is predicted on the basis of S1 protection data. The intensity of the right-angled arrows denotes the relative amounts of transcription initiation detected in the S1 mapping experiments. Open boxes indicate putative Spl-binding sites. Stippled boxes indicate sites closely related to the EGRl consensus sequence: 5'-CGCCCCCGC-3'. The ORFs, within the 5' UTR are underlined. Note that the major ORF encoding the WTl polypeptide begins at nucleotide +723 . $(B, C)$ Two DNA probes, EcoRI-EagI $(B)$ and EagI-PpuMI $(C)$, were prepared and processed for $S 1$ nuclease analysis as described in Materials and methods. The products of the protected species were analyzed on a $6 \%$ polyacrylamide- $8 \mathrm{M}$ urea gel and are labeled I-III. The molecular mass markers (left) are radiolabeled pBR322/MspI-digested DNA. Note that 10 -fold less radioactivity was loaded in the free probe $(-\mathrm{S} 1)$ lane. The tissue sources of the RNA incubated with the S1 probes are indicated at the top.

is facilitated by the use of epitope tagging, which involves engineering into a protein of interest a small peptide sequence recognized by an existing antibody (Field et al. 1988; Kolodziej and Young 1989). We have fused the influenza hemagglutinin (HA) epitope YPYDVPDYAS at the carboxyl terminus of the four WT1 spliced variants (see Materials and methods). Each spliced variant has been placed under control of the cytomegalovirus immediate-early promoter. COS- 1 cells were transfected by electroporation with these expression vectors and, 48 $\mathrm{hr}$ later, processed for immunofluorescence as described in the legend to Figure 8, with mAb 12CA5 directed against the influenza HAl peptide HAl (75-110) (Field et al. 1988). Cells that had not been transfected with any of the WT1 expression vectors never showed staining to the nucleus (Fig. 8A). Cells transfected with all four spliced variants of WT1 demonstrated intense staining localized to the nucleus (Fig. 8B, and data not shown). There was no detectable WT1 in the cytoplasm. It is presently not known whether nuclear localization is intrinsic to WT1 or is caused by its association with other DNA-binding proteins. In either case, the nuclear localization results are consistent with a gene regulatory function for the WT1 protein.

\section{Discussion}

We have described the developmental regulation of the murine WT1 mRNA within the gonads. In the testis we have identified, by in situ RNA hybridization, the Sertoli cells as those cells expressing high levels of WT1. In the ovaries, the granulosa and epithelial cells show high levels of WT1 expression. In addition to the role of WT1 in kidney development, the observations presented in this report implicate WT1 in additional developmental pathways, namely, ovarian and testicular development. What is the role of WT1 in GU development? The most common GU anomalies among individuals with WT-associ- 


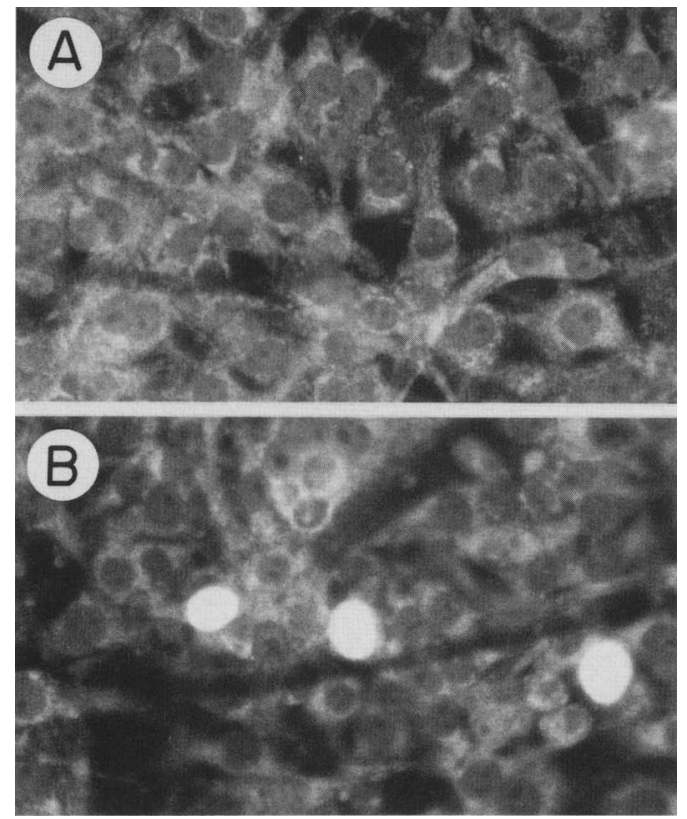

Figure 8. Immunofluorescence studies of the WT1 protein localized within transfected COS-1 cells. Cells were transfected by electroporation $(1200 \mathrm{~V}, 25 \mu \mathrm{F})$ using a Bio-Rad Gene Pulser with PBS buffer $(A)$ or $15 \mu \mathrm{g}$ of $\mathrm{pCMV} / \mathrm{WT} 1-\operatorname{tag}(B)$ (this clone is missing both alternatively spliced exons). Forty-eight hours after seeding cells onto $12-\mathrm{mm}$ glass coverslips, the cells were processed for immunofluorescent staining. Cells were washed once with PBS bulfer and fixed with cold methanol $(-20)$ for 5 min. Fixed and permeabilized cells were hydrated in PBS for 1 min and incubated with $10 \%$ nonimmune rabbit serum in PBS at room temperature for 20 min to suppress nonspecific binding of IgG. Each coverslip was then washed once in PBS and incubated with mAb 12CA5 anti-HA (1:400 dilution) in a moist chamber for $45 \mathrm{~min}$ at room temperature. After three washes in PBS, the coverslips were incubated with $200 \mu \mathrm{l}$ of fluoresceinconjugated goat anti-mouse IgG /Calbiochem; diluted 1:200 in PBS) for $45 \mathrm{~min}$ at room temperature. The coverslips were washed again extensively in PBS and analyzed with a Ziess Axioskop.

ated syndromes are hypospadias, cryptorchidism, and ambiguous genitalia (Miller et al. 1964; Drash et al. 1970). The spectrum of GU anomalies observed among WAGR patients most likely reflects the complexity of sexual development and differentiation during embryogenesis. The internal reproductive systems are derived from the Wolffian and Müllerian ducts that exist side by side in early embryos of both sexes. During development in the male, the Wolffian ducts give rise to the epididymis, vas deferens, and seminal vesicles while the Müllerian ducts regress (for review, see Wilson et al. 1990). The fetal testis accomplishes these tasks by secreting two hormones. Testosterone is produced by Leydig cells and converted to dihydrotestosterone by the target cells; this, in turn, effects male external virilization. Müllerian inhibiting substance (MIS), a glycoprotein produced by Sertoli cells, suppresses development of the Müllerian ducts. In the female, the fallopian tubes, uterus, and up- per vagina are derived from the Müllerian ducts, whereas the Wolffian ducts regress. In the absence of the testis, as in a male embryo castrated prior to onset of gonadal differentiation, development of phenotypic sex proceeds along female lines, demonstrating that masculinization of the fetus is the result of hormone action from the fetal testis; whereas female development does not require the presence of the ovary (Jost 1947).

The failure to detect WT1 expression in Leydig cells (Fig. 4) suggests that WT1 is not directly involved in regulating testosterone production. However, an indirect effect during embryogenesis by Sertoli cells on Leydig cell function and differentiation cannot be excluded. Behringer et al. (1990) have noticed such an effect on Leydig cell function when overexpressing MIS in transgenic mice. Overexpression of MIS in transgenic mice has been shown to interfere with proper development of the male external genitalia, resulting in feminization of the external genitalia (Behringer et al. 1990). In addition, MIS may control testicular descent because a large percentage of patients with undescended testis have defective MIS or MIS receptors (Hutson and Donahoe 1986). Our findings that WT1 is expressed in Sertoli cells and very early in development of the gonads (Pritchard-Jones et al. 1990; this report), coupled with the associated GU anomalies of WAGR patients (cryptorchidism and hypospadias), suggest that WT1 may directly or indirectly modulate the levels of MIS produced by the testis.

An interesting potential upstream/downstream target for WTl action during urogenital system development is the tesis-determining gene Sry. Expression of this gene is first observed 10.5 days p.c. in the genital ridge of male mouse embryos and disappears by 12.5 days p.c. (Koopman et al. 1990). Mutations within SRY in XY females attest to the involvement of this gene product in sexual determination (Berta et al. 1990; Jäger et al. 1990). Expression of WT1 is very high in the testis of a 12.5-day p.c. mouse embryo (Fig. 6B). Current experiments are in progress to determine when WT1 expression is first detected in the gonads of the developing mouse embryo.

GU anomalies among WAGR individuals would therefore represent the dominant expression of a "first hit" at the WT1 locus. This underscores the sensitivity of the developing genital system during embryogenesis because a presumptive $50 \%$ reduction in WTl expression levels can result in abnormal or incomplete differentiation. A similar haploinsufficiency model has been proposed by Fisher et al. (1990), implicating ribosomal protein S4 in Turner syndrome. A mouse model system of the human WAGR deletion syndrome has recently been described (Glaser et al. 1990). The murine WTl gene is hemizygously deleted in Sey ${ }^{\mathrm{dey}} /+$ heterozygotes (Buckler et al. 1991). The absence of urogenital abnormalities affecting kidneys, genitals, or mesonephric structures in Seydey/ + mice suggests that the underlying developmental events or target cells in this species are less sensitive to reduced levels of WT1.

The frequency of occurrence of GU anomalies among the general population is quite high $[0.3 \%$ for hypospadias and $0.8 \%$ for cryptorchidism (Horton and Devine 
1972; Levin and Sherman 1973)]. Their incidence in association with WT is about three- to fivefold higher (Miller et al. 1964; Breslow and Beckwith 1982). The incomplete manifestation of GU anomalies among individuals with WAGR syndrome may represent differences in expressivity among WT1 mutations or differences in underlying sensitivity to fluctuation in WT1 levels. The target genes regulated by WT1 in the gonads probably differ from the target genes under WT1 control in the kidneys during nephrogenesis, considering the differences in developmental regulation and cell-type expression of WT1. The manner by which this regulation is achieved may depend on the presence of transcriptional adaptors necessary to bridge the interaction between WT1 and other components of the basic transcriptional machinery (Berger et al. 1990; Pugh and Tjian 1990). The ratios of the four spliced WT1 mRNA variants are the same in kidney, testis, ovary, and uterus and therefore cannot explain differences in cell-type regulation (D. Haber, B. Sohn, A. Buckler, J. Pelletier, K. Call, and D. Housman, unpubl.). In addition, in situ hybridizations with oligonucleotides targeted to the two different alternatively spliced exons have failed to detect differences in expression among the four WT1 spliced products in testis, ovaries, or uterus (J. Pelletier and M. Schalling, unpubl.).

Sertoli cells in the testis and granulosa cells in the ovary share many structural and functional characteristics and are believed to be derived from a common progenitor cell (Gilman 1948). Both cell types (1) have receptors for follicle-stimulating hormone (FSH) and androgens, (2) synthesize estrogens from testosterone, (3) influence the development of adjacent germinal cells (Fritz 1982), and (4) are derived from the surface epithelium of the gonadal ridge. The functional significance of WT1 expression in the granulosa cells (Fig. 4A) is not clear. WT1 cannot be a positive modulator of MIS in the ovaries, because WT1 expression greatly precedes expression of MIS. Likewise, MIS production by testicular tissue remains fairly stable during the first postnatal days and then wanes progressively. The high levels of WT1 in the adult testis (Fig. 3) suggest additional regulatory roles for the WT1 gene product. Further work is needed to determine whether WT1 regulates common genes in both Sertoli and granulosa cells.

In the mouse, spermatogenesis is an ongoing process that begins soon after birth. Initial appearance of spermatogenic cell types occurs synchronously, and the sequence of events can be followed as a function of increasing age in a variety of mice strains (Bellve et al. 1977). At days 9 or 10 postpartum, spermatogonia first enter meiosis; by day 14 or 15 , the first pachytene spermatocytes are seen; and by day 22 , haploid round spermatids appear (Bellve et al. 1977). The increased levels of expression of WT1 at day 8 postpartum in the testis (Fig. 3A) may somehow be linked to spermatogonia first entering meiosis or may reflect a stage when Sertoli cell proliferation ceases.

Isolation of the WT1 promoter will enable us to dissect the elements responsible for the tissue-specific expres- sion and transcriptional regulation of WT1. The analysis of the WT1 promoter has revealed the following features. The sequence extending from -100 to +600 is highly rich in guanine and cytosine nucleotides. In the sequence immediately upstream of the initiation sites, the typical TATAA element is not found. The presence of three transcriptional start sites and four spliced WT1 mRNA variants indicates that WT1 is a complex transcriptional unit resulting in the possible synthesis of 12 mRNA species. We have been unable to complement the S1 nuclease protection analysis with primer extension studies due to the high G + C content of the WT1 5' UTR. Recently, Blake et al. (1990) have demonstrated that for the TATAA-less dihydrofolate reductase promoter, GC box sequence elements [consensus sequence, 5'-GGGCGG-3'] are not only required for efficient transcription but also regulate start site utilization. It is interesting to note that such elements are found within the WT1 upstream sequences (Fig. 7A). Determining their functional role may be crucial to understanding transcriptional regulation of this class of promoters. Characterization of functional elements within the WT1 promoter responsible for transcription initiation and tissuespecific expression is currently in progress.

In addition to a 3.1-kb WT1 mRNA transcript, we have observed a 2.5-kb mRNA species that hybridizes with the WT1 cDNA and whose expression is confined to the testis (Fig. 1). A similar transcript has been observed by Pritchard-Jones et al. (1990) in RNA from human testis. To date, we have failed to define the alternative processing or initiation event responsible for the smaller $\sim 2.5$ $\mathrm{kb}$ mRNA transcript observed in testis. The production of three WT1 mRNA species either containing or missing two small ORFs within their 5' UTR is suggestive of post-transcriptional control of WT1 gene expression. Small ORFs within the 5' UTR are found in many oncogenes and genes encoding growth hormones and serve to down-modulate the levels of protein synthesized (e.g., see Propst et al. 1988; Garrett et al. 1989|. Given this fact and that secondary structure within the mRNA 5' UTR can affect the efficiency of translation initiation (Pelletier and Sonenberg 1985), we predict that the shorter, more abundant WT1 mRNA species is translated more efficiently than the larger species. Therefore, conditions that affect transcription start site utilization could have drastic effects on the amount of WT1 protein synthesized.

Information on the tissue-specific expression of WT1 may be important for determining the possible involvement of the WT1 gene product in malignancies other than WTs. Abnormalities in structure and expression of RB1 have been implicated in several nonretinoblastoma tumors, which include human breast carcinoma ( $T^{\prime}$ Ang et al. 1988), osteosarcoma (Hansen et al. 1985; Friend et al. 1986), prostate carcinoma (Bookstein et al. 1990), and small cell lung carcinoma (Harbour et al. 1988). The same is true for the p53 gene where mutations in the gene have been shown to occur in many common human malignancies (Nigro et al. 1989; Malkin et al. 1990; Srivastava et al 1990). The tissue-specific expression of 
WT1 is limited to kidney, gonads, uterus, spleen, and peritoneal layers between organs (this report; Call et al. 1990; Pritchard-Jones et al. 1990; Buckler et al. 1991). The finding that WT1 is expressed in ovaries and testis raises the issue of whether inactivation of WT1 contributes to the etiology of ovarian, granulosa, or Sertoli cell tumors.

\section{Materials and methods}

\section{Northern blot analysis}

T'otal RNA was isolated from mouse tissues (C57B6) by the LiCl-urea procedure (Auffray and Rougeon 1980). Briefly, frozen tissue was homogenized at $4^{\circ} \mathrm{C}$ and the RNA was precipitated twice in $3 \mathrm{M} \mathrm{LiCl} / 6 \mathrm{M}$ urea. Following phenol-chloroform extraction and ethanol precipitation, the RNA was resuspended in distilled DEPC-treated water, quantitated by spectrophotometry, and stored at $-70^{\circ} \mathrm{C}$.

DNA fragments were radiolabeled with $\left[\alpha-{ }^{32} \mathrm{P}\right] \mathrm{dCTP}[\mathrm{New}$ England Nuclear (NEN)] according to the random primer method of Feinberg and Vogelstein (1983). Fifteen micrograms of RNA was electrophoresed on $1.2 \%$ agarose $/ 37 \%$ formaldehyde gels and blotted to nitrocellulose (Schleicher \& Schuell). Filters were prehybridized in $50 \%$ formamide, $10 \%$ dextran sulfate, $5 \times$ Denhardt's solution, $0.5 \%$ SDS, $0.1 \%$ sodium pyrophosphate, and $100 \mu \mathrm{g} / \mathrm{ml}$ of salmon sperm DNA at $42^{\circ} \mathrm{C}$ and then hybridized under the same conditions with ${ }^{32} \mathrm{P}$-labeled probe $\left(10^{6} \mathrm{cpm} / \mathrm{ml} ; 5 \times 10^{8} \mathrm{cpm} / \mu \mathrm{g}\right)$. After 2 -day hybridizations, blots were washed twice with $2 \times$ SSC $(1 \times$ SSC: $150 \mathrm{~mm}$ $\mathrm{NaCl}, 15 \mathrm{~mm}$ sodium citrate), $0.1 \% \mathrm{SDS}$ at $55^{\circ} \mathrm{C}$, twice with $0.5 \times \mathrm{SSC}$, and $0.1 \%$ SDS at $65^{\circ} \mathrm{C}$ and exposed to Kodak XAR5 film.

\section{Isolation and sequencing of genomic phage clones}

A genomic phage library (obtained from Dr. Tetsuo Noda) containing average insert sizes of $15-20 \mathrm{kbp}$ in EMBL 3 was screened as outlined by Maniatis et al. (1982). The radiolabeled probe used was a WT1 cDNA clone $(9-1$; described in Buckler et al. 1991) lacking $\sim 1.2 \mathrm{kbp}$ from the $5^{\prime}$ end. Phage DNA was isolated from small-scale cultures of each positive clone according to Maniatis et al. (1982), and the restriction pattern of each phage clone was analyzed by standard agarose gel electrophoresis and Southern blotting analysis. A 6-kbp BamHI-BgIII fragment estimated by Southern blotting to extend $\sim 3 \mathrm{kbp}$ upstream of our longest WT1 cDNA was subcloned into the BamHI site of pBluescript II SK + . This plasmid is referred to as 41 Bgl6.

DNA sequences were determined by the dideoxy chain-termination method (Sanger et al. 1977). Regions of G + C compression were resequenced using 7-deaza-dGTP and Sequenase (U.S. Biochemical Corp.). Direct sequencing primers of pBluescript II SK + (Strategene) were obtained from U.S. Biochemical Corp. Additional oligonucleotides were synthesized by the MIT Biopolymers Laboratory.

\section{S1 nuclease analysis}

A plasmid containing a genomic fragment encompassing the WT1 gene 5' UTR and upstream sequences (41Bgl6) was restricted with PpuMI or EagI (see Fig. 7A), phosphatase-treated with calf intestinal alkaline phosphatase [Boehringer Mannheim Corp. (BMC)], and radiolabeled with $\left[\gamma^{32}\right.$ P]ATP and polynucleotide kinase (New England Biolabs). The plasmid was then restricted with EagI or EcoRI (see Fig. 7A), and the DNA fragment spanning the WT1 $5^{\prime}$ UTR was purified from a $0.8 \%$ low-melt agarose gel as described by Langridge et al. (1980). S1 nuclease analyses were performed as described (Maniatis et al. 1982). Fifty micrograms of total RNA was ethanol-precipitated with $30,000 \mathrm{cpm}$ of radiolabeled probe, resuspended in $20 \mu \mathrm{l}$ of formamide buffer $(80 \%$ formamide, $40 \mathrm{mM}$ PIPES at $\mathrm{pH} 6.4,400$ $\mathrm{mM} \mathrm{NaCl}, 1 \mathrm{~mm}$ EDTA), denatured at $90^{\circ} \mathrm{C}$ for $10 \mathrm{~min}$, and incubated at $55^{\circ} \mathrm{C}$ for $12 \mathrm{hr}$. The samples were treated with 300 units of $\mathrm{S} 1$ nuclease (BMC) at $30^{\circ} \mathrm{C}$ for $30 \mathrm{~min}$, ethanol-precipitated, and analyzed on a $6 \%$ polyacrylamide- $8 \mathrm{M}$ urea gel.

\section{In situ RNA hybridizations}

Two 50-nucleotide oligonucleotides were synthesized by the MIT Biopolymers Laboratory and subsequently gel-purified on a $6 \%$ polyacrylamide $/ 8 \mathrm{M}$ urea gel. The oligonucleotides were both the sense and antisense strand of the following sequence of the murine WT1-coding region (Buckler et al. 1991) (nucleotides 1173-1223): 5'-GCTTGAATGCATGACCTGGAATCAGATGAACCTAGGAGCTACCTTAAAGG-3'. The oligonucleotides were labeled at the $3^{\prime}$ end by terminal deoxynucleotidyltransferase (Bethesda Research Laboratories) and $\left[\alpha^{-{ }^{35}} S\right] \mathrm{dATP}$ (NEN) to a sp. act. of $1.2 \times 10^{9} \mathrm{cpm} / \mu \mathrm{g}$.

Protocols for hybridizations were essentially as described previously (Schalling et al. 1990). Slides were incubated at $42^{\circ} \mathrm{C}$ for $16-18 \mathrm{hr}$ in a moist chamber with $1 \times 10^{6} \mathrm{cpm}$ of labeled probe per $100 \mu \mathrm{l}$ of hybridization fluid containing $50 \%$ formamide, $4 \times$ SSC, $1 \times$ Denhardt's solution, $1 \%$ sarcosyl, $0.02 \mathrm{M} \mathrm{NaHPO}_{4}(\mathrm{pH}$ $7.0), 10 \%$ dextran sulfate, $500 \mu \mathrm{g} / \mathrm{ml}$ of salmon sperm DNA (Sigma), and $200 \mathrm{~mm}$ dithiothreitol (DTT) (LKB: Bromma, Sweden). After hybridization, the sections were sequentially rinsed in four changes of $1 \times \mathrm{SSC}$ at $55^{\circ} \mathrm{C}$ for $60 \mathrm{~min}$ and distilled water at room temperature for $1 \mathrm{~min}$ and dehydrated in $60 \%$ and $95 \%$ ethanol. After air-drying, the sections were put in X-ray cassettes and exposed to Hyperfilm $\beta$-max X-ray film (Amersham) for 3 days, and then dipped in NTB2 nuclear track emulsion (Kodak). After exposure at $-20^{\circ} \mathrm{C}$ for 3-16 days, slides were developed in D19 (Kodak; $16^{\circ} \mathrm{C}$ ) for $3 \mathrm{~min}$ and fixed for $3 \mathrm{~min}$. After rinsing, the sections were either mounted directly in glycerol-phosphate $\{3: 1\}$ buffer or dehydrated in xylene and mounted in Paramount (Sigma). Sections were stained with crystal violet, Sudan black, or hematoxylin-eosin to identify the cellular components. Sections were analyzed in a microscope equipped for bright- and dark-field illumination (Zeiss Axioskop) and photographed using T-Max 100 black-and-white film (Kodak).

\section{Influenza $H A$ epitope tagging}

The influenza HA epitope YPYDVPDYAS (Field et al. 1988; Kolodziej and Young 1989) was engineered into the WTI gene as follows. An oligonucleotide containing the influenza HA epitope nucleotide sequence adjacent to the WT1 carboxyl terminus was synthesized by the MIT Biopolymers Laboratory. This oligonucleotide, which places the HA epitope at the carboxyl terminus of WT1, was used in conjunction with an upstream oligonucleotide /targeted to nucleotides 1118-1134; see Buckler et al. 1991) to amplify via PCR the carboxy-coding region of WTl. PCR was performed with Taq polymerase (PerkinElmer) as outlined by the manufacturer's recommended conditions with $50 \mathrm{ng}$ of DNA /a cDNA encompassing the entire WT1-coding region was used) in a total volume of $100 \mu l$. Thirty cycles of amplification were carried out on a Perkin-Elmer PCR machine. Each cycle consisted of $1 \mathrm{~min}$ at $94^{\circ} \mathrm{C}, 2 \mathrm{~min}$ at $60^{\circ} \mathrm{C}$, and $3 \mathrm{~min}$ at $72^{\circ} \mathrm{C}$. Following completion of the PCR, 50- $\mu \mathrm{l}$ aliquots were withdrawn, phenol-extracted, ethanol-precipi- 
tated, and restricted with RsrII and SalI. The RsrII-Sall fragment containing the epitope tag was purified from a $3 \%$ Nusieve gel as described (Langridge et al. 1980) and cloned into the WT1-coding domain. The WT1-HA domain obtained by PCR amplification was sequenced by the method of Sanger et al. (1977) to ensure that no mutations had occurred during PCR. The WT1-HA tag gene (containing the WT1-coding region fused to the HA epitope tag, as well as 23 nucleotides upstream of the WT1 AUGl, was placed under control of the cytomegalovirus promoter for expression studies. Transfection and immunofluorescence of COS-1 cells were performed as described in the legend to Figure 8.

\section{Acknowledgments}

We thank Wendy Bruening and Drs. Vincent Stanton, Marc Timmers, David Munroe, David Brook, and Hiro Aburitani for helpful discussions during the course of this work and for their comments on the manuscript. We thank Dr. Edwin Geissler for kindly providing testis from $\mathrm{W} / \mathrm{W}^{\mathrm{v}}$ and $\mathrm{SI} / \mathrm{SI}^{\mathrm{d}}$ mice and Dr. Robert Arceci for helpful discussions and comments on in situ RNA hybridization studies during the course of this work. We thank Drs. Ann Graybiel and Alice Flaherty for advice and use of darkroom facilities. We gratefully acknowledge Dr. Tetsuo Noda (MIT-Whitehead Institute) for generously providing the partial Sau3A1 mouse D3 genomic library. J.P. is supported by a fellowship from the Medical Research Council of Canada. M.S. was supported by a postdoctoral fellowship from the European Molecular Biology Organization. A.J.B. was supported by fellowship CA08605 from the National Institutes of Health (NIH). D.A.H. was supported by National Cancer Institute Clinical Investigator Award 1K080CA 01356. This work was supported by NIH grant GM27882 to D.H.

The publication costs of this article were defrayed in part by payment of page charges. This article must therefore be hereby marked "advertisement" in accordance with 18 USC section 1734 solely to indicate this fact.

\section{References}

Auffray, C. and F. Rougeon. 1980. Purification of mouse immunoglobulin heavy-chain messenger RNAs from total myeloma tumor RNA. Eur. J. Biochem. 107: 303-314.

Beckwith, J.B., N.B. Kiviat, and J.F. Bonadio. 1989. Nephrogenic rests, nephroblastomatosis, and the pathogenesis of Wilms' tumor. Pediatr. Pathol. 10: 1-36.

Behringer, R.R., R.L. Cate, G.J. Froelick, R.D. Palmiter, and R.L. Brinster. 1990. Abnormal sexual development in transgenic mice chronically expressing Müllerian inhibiting substance. Nature 345: 167-170.

Bellve, A.R., J.C. Cavicchia, C.F. Millette, D.A. O'Brien, Y.M. Bhatnagar, and M. Dym. 1977. Spermatogenic cells of the prepuberal mouse. Isolation and morphological characterization. J. Cell. Biol. 74: 68-85.

Bennett, D. 1956. Developmental analysis of a mutation with pleiotropic effects in the mouse. J. Morphol. 98: 199-234.

Berger, S.L., W.D. Cress, A. Cress, S.J. Triezenberg, and L. Guarente. 1990 Selective inhibition of activated but not basal transcription by the acidic activation domain of VP16: Evidence for transcriptional adaptors. Cell 61: 1199-1208.

Berta, P., J.R. Hawkins, A.H. Sinclair, A. Taylor, B.L. Griffiths, P.N. Goodfellow, and M. Fellous. 1990. Genetic evidence equating SRY and the testis-determining factor. Nature 348: 448-450.

Blake, M.C., R.C. Jambon, A.G. Swick, J.W. Kahn, and J.C. Azizkhan. 1990. Transcriptional initiation is controlled by up- stream GC-box interactions in a TATAA-less promoter. Mol. Cell. Biol. 10: 6632-6641.

Bookstein, R., J.-Y. Shew, P.-L. Chen, P. Scully, and W.-H. Lee. 1990. Suppression of tumorigenicity of human prostate carcinoma cells by replacing a mutated RB gene. Science 247: 712-715.

Breslow, N.E. and J.B. Beckwith. 1982. Epidemiological features of Wilms' tumor: Results from the first National Wilms' Tumor Study. Cancer 41: 1937-1948.

Breslow, N.E., J.B. Beckwith, M. Ciol, and K. Sharples. 1988. Age distribution of Wilms' tumor: Report from the National Wilms' Tumor Study. Cancer Res. 48: 1653-1657.

Buckler, A.J., J. Pelletier, D. Haber, T. Glaser, and D.E. Housman. 1991. The murine Wilms' tumor gene (WT1): Isolation, characterization, and expression during kidney development. Mol. Cell. Biol. 11: 4707-4712.

Call, K.M., T. Glaser, C.Y. Ito, A.J. Buckler, J. Pelletier, D.A. Haber, E.A. Rose, A. Kral, H. Yeger, W.H. Lewis, C. Jones, and D.E. Housman. 1990. Isolation and characterization of a zinc finger polypeptide gene at the human chromosome 11 Wilms' tumor locus. Cell 60: 509-520.

Drash, A., W.H. Hartman, and R.M. Blizzard. 1970. A syndrome of pseudohermaphroditism, Wilms' tumor, hypertension, and degenerative renal disease. $/$. Pediatr. 76: 585-593.

Feinberg, A.P. and B. Vogelstein. 1983. A technique for radiolabeling DNA restriction fragments to high specific activity. Biochem. Biophys. Res. Commun. 111: 47-54.

Field, J., J.-I. Nikawa, D. Broek, B. MacDonald, L. Rodgers, I.A. Wilson, R.A. Lemer, and M. Wigler. 1988. Purification of a RAS-responsive adenylyl cyclase complex from Saccharomyces cerevisiae by use of an epitope addition method. Mol. Cell. Biol. 8: 2159-2165.

Fisher, E.M.C., P. Beer-Romero, L.G. Brown, A. Ridley, J.A. McNeil, J.B. Lawrence, H.F. Willard, F.R. Bleber, and D.C. Page. 1990. Homologous ribosomal protein genes on the human X and $\mathrm{Y}$ chromosomes: Escape from $\mathrm{X}$ inactivation and possible implications for Turner syndrome. Cell 63: 1205-1218.

Francke, U., L.B. Holmes, L. Atkins, and V.M. Riccardi. 1979. Aniridia-Wilms' tumor association: Evidence for specific deletion of 11p13. Cytogenet. Cell Genet. 24: 185-192.

Friend, S.H., R. Bernards, S. Rogelj, R.A. Weinberg, J.M. Rapaport, D.M. Alberts, and T.P. Dryja. 1986. A human DNA segment with properties of the gene that predisposes to retinoblastoma and osteosarcoma. Nature 323: 643-646.

Fritz, I.B. 1982. Comparison of granulosa and Sertoli cells at various stages of maturation: Similarities and differences. In Intraovarian control mechanisms (ed. C.P. Channing and S.J. Segal), pp. 357-384. Plenum Publishing, New York.

Garrett, J.E., M.W. Collard, and J.O. Douglass. 1989. Translational control of germ cell-expressed mRNA imposed by alternative splicing: Opioid peptide gene expression in rat testis. Mol. Cell. Biol. 9: 4381-4389.

Gessler, M., A. Poustka, W. Cavenee, R.L. Neve, S.H. Orkin, and G.A.P. Bruns. 1990. Homozygous deletion in Wilms' tumors of a zinc-finger gene identified by chromosome jumping. Nature 343: 774-778.

Gilman, J. 1948. The development of the gonads in man, with consideration of the role of fetal endocrines and the histogenesis of ovarian tumors. Contributions Embryol. 210, Carnegie Inst. Washington Publ. 32: 81.

Glaser, T., C. Jones, E.C. Douglass, and D. Housman. 1989. Constitutional and somatic mutations of chromosome $11 \mathrm{p}$ in Wilms' tumor. In Cancer cells. Molecular diagnostics of human cancer (ed. M. Furth and M. Greaves), Vol. 7, pp. 253-277. Cold Spring Harbor Laboratory Press, Cold Spring Harbor, New York. 
Glaser, T., J. Lane, and D. Housman. 1990. Dickie's small-eye mutation (Sey ${ }^{D e y}$ ); A mouse model of the aniridia-Wilms' tumor deletion syndrome. Science 250: 823-827.

Haber, D.A., A.J. Buckler, T. Glaser, K.M. Call, J. Pelletier, R.L. Sohn, E.C. Douglass, and D.E. Housman. 1990 An internal deletion within an $11 \mathrm{p} 13$ zinc finger gene contributes to the development of Wilms' tumor. Cell 61: 1257-1269.

Hansen, M.F., A. Koufos, B.L. Gallie, R.A. Phillips, O. Fodstad, A. Brogger, T. Gedde-Dahl, and W.K. Cavenee. 1985. Osteosarcoma and retinoblastoma: A shared chromosomal mechanism revealing recessive predisposition. Proc. Natl. Acad. Sci. 82: 6216-6220.

Harbour, J.W. , S.L. Lai, P.J. Whang, A.F. Gazdar, J.D. Minna, and F.J. Kaye. 1988. Abnormalities in structure and expression of the human retinoblastoma gene in SCLC. Science 241: 353-357.

Horton, C. and C. Devine. 1972. Hypospadias and epispadias. Clin. Symp. 24(3).

Huff, V., H. Miwa, D.A. Haber, K.M. Call, D.E. Housman, L.C. Strong, and G.F. Saunders. 1991. Evidence for WT1 as a Wilms' tumor (WT) gene: Intragenic germinal deletion in bilateral WT. Am. J. Hum. Genet. 48: 997-1003.

Hutson, J.M. and P.K. Donahoe. 1986. The hormonal control of testicular descent. Endocr. Rev. 7: 270-283.

Jäger, R.I., M. Anvret, K. Hall, and G. Scherer. 1990. A human $\mathrm{XY}$ female with a frameshift mutation in the candidate testis-determining gene SRY. Nature 348: 452-454.

Jones, N.C., P.W.J. Rigby, and E.B. Ziff. 1988. Trans-acting protein factors and the regulation of eukaryotic transcription: Lessons from studies on DNA tumor viruses. Genes \& Dev. 2: $267-281$.

Jost, A. 1947. Recherches sur la différenciation sexuelle de l'embryon lapin. III. Rôle des gonades foetales dans la différenciation sexuelle somatique. Arch. Anat. Microsc. Morphol. Exp. 36: 271-315.

Kolodziej, P. and R.A. Young. 1989. RNA polymerase II subunit RPB3 is an essential component of the mRNA transcription apparatus. Mol. Cell. Biol. 9: 5387-5394.

Koopman, P., A. Munsterberg, B. Capel, N. Vivian, and R. Lovell-Badge. 1990. Expression of a candidate sex-determining gene during mouse testis differentiation. Nature 348: 450452.

Langridge, J., P.Langridge, and P.L. Berquist. 1980. Extraction of nucleic acid from agarose gels. Anal. Biochem. 103: 264271.

Levin, A. and J.O. Sherman. 1973. The undescended testis. Surg. Gynecol. Obstet. 136: 473-479.

Lewis, W.H., H. Yeger, L. Bonetta, H.S.L. Chan, J. Kang, C. Junien, J. Cowell, C.A. Jones, and L.A. Defoe. 1988. Homozygous deletion of a DNA marker from chromosome $11 \mathrm{p} 13$ in sporadic Wilms' tumor. Genomics 3: 25-31.

Malkin, D., F.P. Li, L.C. Strong, J.F. Fraumeni, Jr., C.E. Nelson, D.H. Kim, J. Kassel, M.A. Gryka, F.Z. Bischoff, M.A. Tainsky, and S.H. Friend. 1990. Germ-line p53 mutations in a familial syndrome of breast cancer, sarcomas, and other neoplasms. Nature 250: 1233-1238.

Maniatis, T., E.F. Fritsch, and J. Sambrook. 1982. Molecular cloning: A laboratory manual. Cold Spring Harbor Laboratory, Cold Spring Harbor, New York.

Matsunaga, E. 1981. Genetics of Wilms' tumor. Hum. Genet. 57: 231-246.

Miller, R.W., J.F. Fraumeni Jr., and M.D Manning. 1964. Association of Wilms' tumor with aniridia, hemihypertrophy and other congenital mallormations. New Engl. I. Med. 270: 922-927.

Mintz, B. and E.S. Russel. 1957. Gene-induced embryological modifications of primordial germ cells in the mouse. I. Exp. Zool. 134: 207-237.

Nigro, J.M., S. J. Baker, A.C. Preisinger, J. Milburn Jessup, R Hostetter, K. Cleary, S.H. Bigner, N. Davidson, S. Baylin, P. Devilee, T. Glover, F.S. Collins, A. Weston, R. Modali, C.C. Harris, and B. Vogelstein. 1989. Mutations in the p53 gene occur in diverse human tumor types. Nature 342: 705-708.

Pelletier, J. and N. Sonenberg. 1985. Insertion mutagenesis to increase secondary structure within the $5^{\prime}$ noncoding region ofa eukaryotic mRNA reduces translational efficiency. Cell 40: $515-526$.

Pendergrass, T.W. 1976. Congenital anomalies in children with Wilms' tumor. Cancer 37: 403-409.

Pritchard-Jones, K., S. Fleming, D. Davidson, W. Bickmore, D. Porteous, C. Gosden, J. Bard, A. Buckler, J. Pelletier, D. Housman, V. van Heyningen, and N. Hastie. 1990. The candidate Wilms' tumor gene is involved in genitourinary development. Nature 346: 194-197.

Propst, F., M.P. Rosenberg, and G.F. Vande Woude. 1988. Protooncogene expression in germ cell development. Trends Genet. 4: 183-187.

Pugh, B.F and R. Tjian. 1990. Mechanism of transcriptional activation by Sp1: Evidence for coactivators. Cell 61: 11871197.

Rauscher, F.J. III, J.F. Morris, O.E. Tournay, D.M. Cook, and T. Curran. 1990. Binding of the Wilms' tumor locus zinc finger protein to the EGR-1 consensus sequence. Science 250: 1259-1261.

Riccardi, V.M., E. Sujansky, A.C. Smith, and U. Francke. 1978. Chromosomal imbalance in the Aniridia-Wilms' tumor association $11 \mathrm{p}$ interstitial deletion. Pediatrics 61: 604-610.

Sanger, A.F., S. Nicklen, and A.R. Coulson. 1977. DNA sequencing with chain-terminating inhibitors. Proc. Natl. Acad. Sci. 74: 5463-5467.

Schalling, M., K. Friberg, K. Seroogy, P. Riederer, E. Bird, S.N. Schiffmann, P. Mailleux, J.-J. Vanderhaeghen, S. Kuga, M. Goldstein, K. Kitahama, P.H. Luppi, M. Jouvet, and T. Hokfelt. 1990. Analysis of expression of cholecystokinin in dopamine cells in the ventral mesencephalon of several species and in humans with schizophrenia Proc. Natl. Acad. Sci. 87: 8427-8431.

Srivastava, S., Z. Zou, K. Pirollo, W. Blattner and E.H. Chang. 1990. Germ-line transmission of a mutated p53 gene in a cancer-prone family with Li-Fraumeni syndrome. Nature 348: $747-749$.

T'Ang, A., J.M. Varley, S. Chakraborty, A.L. Murphree, and Y.K.T. Fung. 1988. Structural rearrangement of the retinoblastoma gene in human breast carcinoma. Science 242: 263242.

Turleau, C., J. de Grouchy, J.L. Dilier, P.L. Hoang, P.H. Schmelck, R. Rappaport, C. Nihoul-Fekete, and N. Diebold. 1981. Aniridia-male psuedohermaphroditism-gonadoblastoma-mental retardation and del $11 \mathrm{pl3}$. Hum. Genet. 57: 300306.

van Heyningen, V., W.A. Bickmore, A. Seawright, J.M. Fletcher, J. Maule, G. Fekete, M. Gessler, G.A.P. Bruns, C. HuerreJeanpierre, C. Junien, B.R.G. Williams, and N.D. Hastie. 1990. Role for the Wilms' tumor gene in genital development. Proc. Nat1. Acad. Sci. 87: 5383-5386.

Waters, S.H., R.J. Distel, and N.B. Hecht. 1985. Mouse testis contain two size classes of actin mRNA that are differentially expressed during spermatogenesis. Mol. Cell. Biol. 5: 1649-1654.

Wilson, J.D., E. Braunwald, K.J. Isselbacher, R.G. Petersdorf, J.B.Martin, A.C. Fauci, and R.K. Root. 1990. Harrison's principles of internal medicine. McGraw-Hill, New York. 


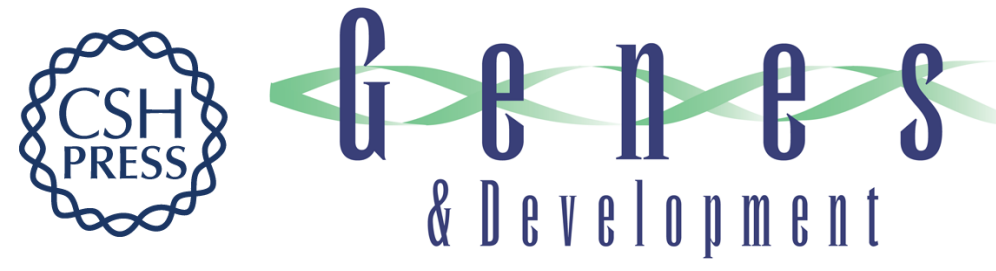

\section{Expression of the Wilms' tumor gene WT1 in the murine urogenital system.}

J Pelletier, M Schalling, A J Buckler, et al.

Genes Dev. 1991, 5:

Access the most recent version at doi:10.1101/gad.5.8.1345

References This article cites 55 articles, 17 of which can be accessed free at: http://genesdev.cshlp.org/content/5/8/1345.full.html\#ref-list-1

License

Email Alerting

Service

Receive free email alerts when new articles cite this article - sign up in the box at the top right corner of the article or click here.

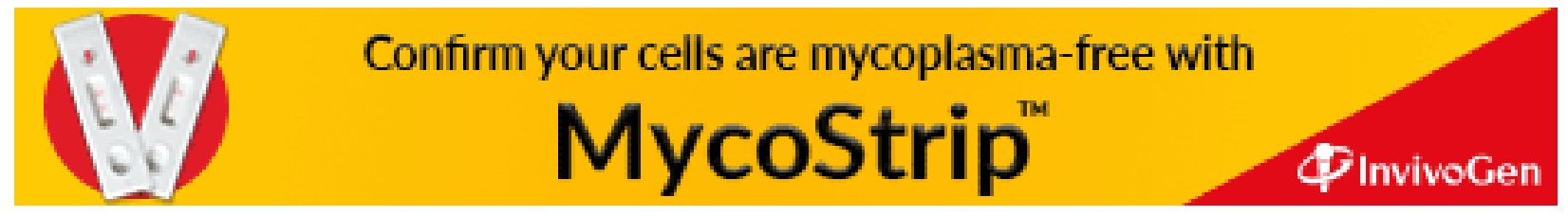

